\title{
The Baikal Basin as a Transboundary Ecological and Economic System
}

\author{
Darima A. Darbalaeva, Anna S. Mikheeva \\ Laboratory of Environmental Economics, Baikal Institute for Nature Management SB RAS, Ulan-Ude, Russian \\ Email: darimchik@rambler.ru, asmiheeva@binm.bscnet.ru
}

Received 7 May 2015; accepted 19 August 2015; published 25 August 2015

\begin{abstract}
This article considers a necessity to assign the Baikal basin as an integrated transboundary ecological-economic system where an incongruity of global ecological and local economic interests is observed. The existing problems and limitations of further development of the Baikal ecological-economic system are singled out.
\end{abstract}

\section{Keywords}

\section{Lake Baikal, Ecological-Economic System, Transboundary Character, Lake Basin}

\section{Introduction}

The topicality of studies of an interaction between economic development and environment protection is primarily caused by the fact that nowadays separate methods of administering economic development on the one hand and nature management and protection on the other hand dominate the solution of ecological and economic problems. A guarantee of harmonious economic development and conservation of environment is not merely an isolated scrutiny of ecosystemic problems or economic growth issues, but their analysis in the aggregate, which in general forms an ecological-economic system.

\section{The Ecological-Economic System}

The notion of the ecological-economic system has long been in existence and use in economic and ecological literature. Academician M. Y. Lemeshev (1976) defined the ecological-economic system as "integration of economics and nature representing an interacted and interdependent functioning of public production and passing of natural processes in the environment” [1]. In principle any controllable object (from an enterprise, region, and country to the entire world community) should be considered an ecological-economic system.

Nowadays in scientific literature one can find many different interpretations of ecological-economic systems. The ecological-economic system that we envisage is a joint functioning of economic and ecological subsystems, in which various kinds of structures and processes are connected by mutually supportive streams of substance, energy and information and natural capital is the main sphere of interaction of subsystems (Figure 1). The ecological subsystem or ecosystem is a natural environment, which is the basis of the humanity's existence and, 


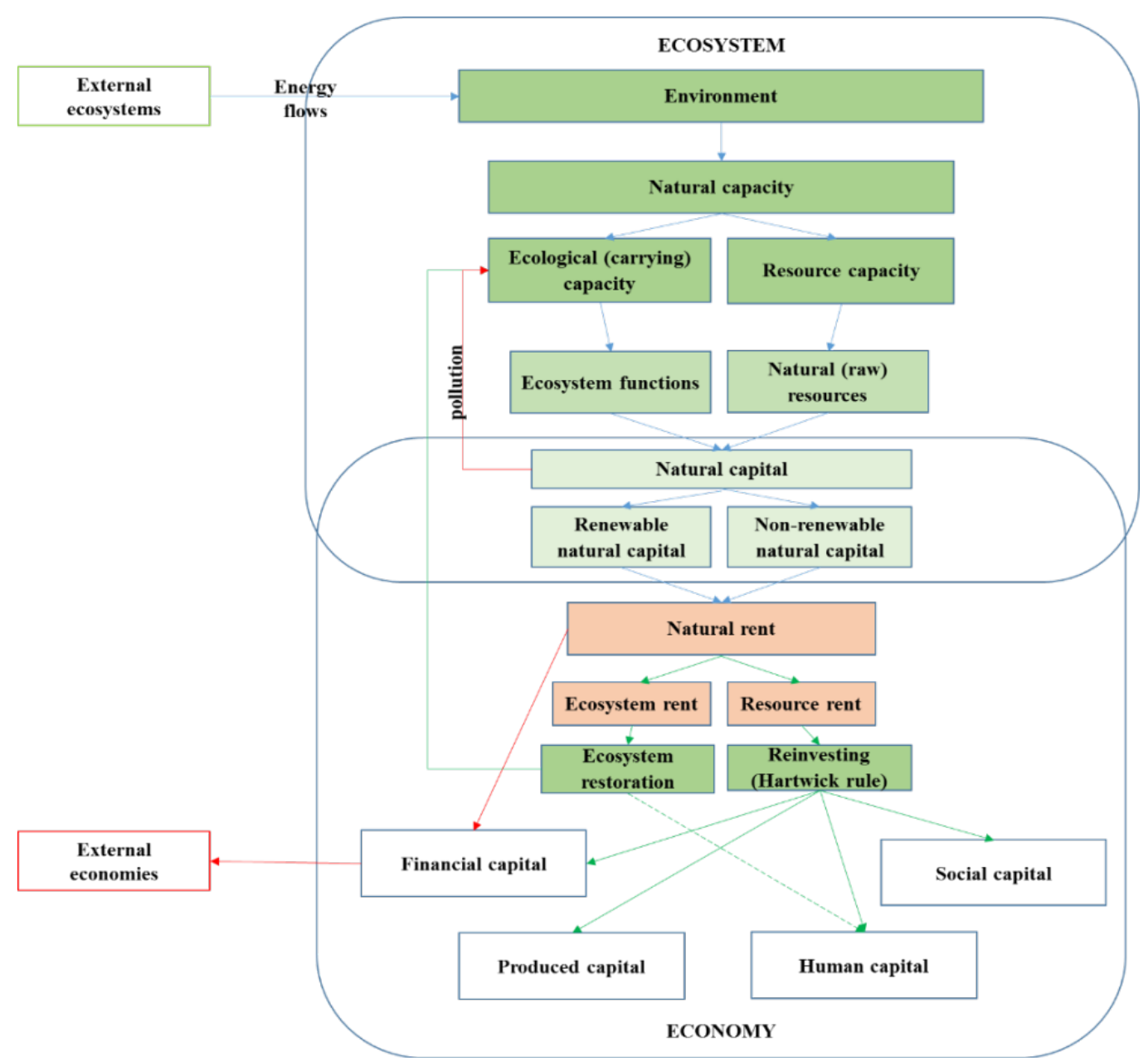

Figure 1. A scheme of an ecological-economic system.

consequently, of all its economic activity. Thus, it is primary to the economic subsystem embracing all existing resources (water, minerals, oil, timber, fish, soil, air and so on) and ecosystem services produced as a result of ecosystem functions. The economic subsystem, in our understanding, is a total of five capitals (manufactured capital, human capital, social capital, financial capital and natural capital) and relationships among them. In other words, the total of these capitals represents national wealth of a country or region.

Natural capacity encompasses both elements and forces of nature available for use and those unavailable at present, but possibly usable in the future when science and technologies will be developed enough to allow this. Natural capacity consists of ecological capacity, or carrying capacity, and resource capacity. Natural resources as raw material are a part of the resource capacity available for involvement into the economy while ecosystem functions are a part of the ecological capacity. Natural capital is related to both ecological and economic subsystems. Drawing into economic circulation and generation of revenue are a condition of a transfer of the natural resources or ecosystem functions into the natural capital. Thus, natural capital is an asset that generates revenue in a form of natural rent as a result of economic activity. In its turn, by its origin natural rent is divided into ecosystem and resource (extractive).

The functioning of the ecological-economic system is as follows: the ecosystem receives energy flows. They cause various natural processes to occur. The resources of natural environment of various kinds get from the ecosystem to the economy while pollutions return and these flows represent the consumption of natural capital. As the economy develops more and more natural raw materials are drawn into economic circulation. In this way, with the development of science and technology, the borders of natural capital broaden to reach the borders of natural capacity. According to Hartwick rule revenue generated in the course of exploitation of non-renewable 
natural capital in the form of natural rent should be reinvested into other types of capital. Thus, a country with economy heavily dependent on non-renewable resources, such as oil, should reinvest the royalty generated in the course of exploitation of these resources in capital goods for modernization of productive assets or in human capital in a form of free education or healthcare. Revenue generated from using of ecosystem functions should be spent on ecosystem restoration and maintaining of their sustainable functioning.

However, this is the way an ideal ecological-economic system looks. In it, borders of an ecosystem coincide with the administrative boundaries of regions or states. In reality, usually there are several ecosystems on the territory of a country. As applied to the ecosystem of Lake Baikal, such characteristic feature as state border is added, i.e. one ecosystem is situated on the territory of two states and two different economic systems. Due to this, various problems of nature management occur. The Baikal region is a vivid example of how global ecological and local economic interests disagree.

\section{The Baikal Basin and Its Problems}

Lake Baikal is the deepest lake on the globe. Its maximum depth reaches $1637 \mathrm{~m}$. With its colossal water volume of 23.000 cubic $k \mathrm{~km}$ Lake Baikal occupies the first place in the world. The lake contains $20 \%$ of global surface water reserves and over 90\% of Russia's reserves. Water of Lake Baikal is crystal clear. Water transparency reaches the depth of $40 \mathrm{~m}$. Water surface area is $31.500 \mathrm{sq} \cdot \mathrm{km}$ and water catchment area is about 540.000 $\mathrm{sq} \cdot \mathrm{km}$. Over 300 rivers and streams run into the lake. Over a half of the influent is supplied by the Selenga River. The Angara is the only river flowing out of the lake. Out of 2630 species and subspecies of animals and plants over 2000 species are endemics. Over 20 new species of invertebrates are discovered and described in Lake Baikal annually [2]. In accordance with the Convention on the Protection for the Protection of the World Cultural and Natural Heritage in 1996 Lake Baikal received a status of the World Natural Heritage Site.

\subsection{The "Baikal Factor"}

Ecological zones with special conditions of nature management are installed within the limits of the Russian part of the catchment basin of Lake Baikal, most of which is located in the Republic of Buryatia. The system of ecological regulation of economic activity limits volumes of final felling, bans on mining and use of mineral fertilizers and pesticides in agriculture. Strict ecological norms on pollution emissions and discharges are in effect. In the contemporary economic conditions economic entities and local population do not get the full amount of benefits from the use of the available natural resources and benefits. Regional economy has long been in decline and currently suffers financial losses in connection with the "Baikal factor". The produce of local manufacturers is non-competitive on the market and over $30 \%$ of the population is below the poverty line.

\subsection{Biological Contamination}

A small, warm and shallow lake Kotokel in $2 \mathrm{~km}$ from the shore of Lake Baikal became known in 2008-2011 because in this period 21 Haff disease cases in humans were registered. Mass mortality of fish, piscivorous birds and pets was observed. The outbreak of Haff disease on the Kotokel Lake was preceded by the invasion and mass die-off of the alien Canadian pondweed (Elodea Canadensis), contamination of the lake by waste water, aridity and high temperatures in summer, which, in the aggregate, contributed to the growth of toxic algae species in the lake [3]. The population carrying capacity of self-purification of the small Kotokel Lake, which used to be a popular recreation site, was considerably exceeded. As a result, the man-made pressure led to the environmental disaster. The same alien algae species infected many bays and gulfs of Baikal where its emergence was first registered in 1980 [4].

In summer 2014, the spirogyra alien algae species started massively spreading in Lake Baikal. The main reason for this was supposed to be waste water discharges by tourist facilities and use of phosphorus-containing detergents by unorganized tourists who washed their clothes and dishes in the lake. Unique water-filtering freshwater sponges started to die off in the lake. According to the data of the Limnological Institute of the Siberian Branch of the Russian Academy of Sciences, from 10\% to 100\% of damaged or dead branched sponges were found depending on a study area. Besides, mass sell-fish mortality was registered in some areas.

\subsection{Fires}

From year to year forests burn in the Baikal basin. Over the recent years, each spring as the forest fire season 
commences emergency situation regime has been introduced in the Republic of Buryatia. Entering woods is strictly forbidden during such periods. According to the statistics most forest fires start near settlements and the human factor is the cause of $80 \%$ of forest fires. However, in reality a significant proportion of forest fires are acts of arson, i.e. crimes connected with illegal felling. First, forest is "accidentally" ignited. Then burned (and often intact) forest, for which it is much easier to get a felling permit, is cut over and sold.

Last summer and autumn were marked by prolonged peat-bog fires in the shoreline part of the Kabansky district of the republic. This area was completely covered by smoke from permanently smoldering peat bogs. As a result visibility fell so low that it led to a deadly car crash on a nearby road. Burning of peat bogs was caused by marsh drainage though the Kabansky district is considered to be rather moist.

\subsection{Overfishing}

Baikal omul is an endemic fish species. It is a commercially valuable fish, a means of subsistence for the inhabitants of the settlements on the shore of Lake Baikal. According to the data of state report on the condition of Lake Baikal in 2013, a decrease of the species biomass of all morphoecological omul groups from 20.5 - 26.4 thousand tons (1982-2005) to 16.6 - 21.4 thousand tons in 2006-2013. In 2013 the total number of producers of Baikal omul entering spawning rivers amounted to 2 million, which is more than two times less than the longtime average annual level of 4.2 million. In the Upper Angara River, the lowest number of seed-omul in over 30 years was registered -1 million. The reasons are the general decrease of the resources of this morphological group and illegal fishing of seed-fish in summer. The real yield in 2013 was 1870 tons. Out of this figure 39\% are illegal fishing. As a result the scientists proposed to decrease the allowed yield of fishery resources. Besides, despite a long-term ban on fishing Baikal sturgeon and measures to artificially reproduce it, there is no visible replenishment of its resources in the lake. Also there is a threat of extinction of cisco in Lake Baikal. The main cause of this is poaching [3].

\subsection{River Runoff}

River runoff is the main component of annual replenishment of water resources of Lake Baikal. Rivers supply 82.4\% of the total water inflow in the hydrological balance of Lake Baikal, while precipitation brings $13.2 \%$ and groundwater runoff forms $4.4 \%$. The catchment basin of Lake Baikal embraces the territory of Russia (240.5 thousand sq $\cdot \mathrm{km}$ in total, 171 thousand sq. $\mathrm{km}$ in the Republic of Buryatia, 55.8 thousand sq.km in the Chita region, 12.5 thousand sq. $\mathrm{km}$ in the Irkutsk region and 1.8 thousand sq.km in the Republic of Tyva) and Mongolia ( 300.5 thousand sq $\cdot \mathrm{km}$ ). The transboundary Selenga River is the main tributary of Lake Baikal as it brings a half of all water supply and $46 \%$ of the annual runoff of the river is formed in Mongolia.

The present low-flow on Lake Baikal is the longest over the last 100 years. According to the Ministry of Emergency Situations of Russia the water supply in the lake in summer and autumn 2014 amounted to merely $67 \%$ of the norm.

The low inflow of water in the lake from the rivers, disruption of water-regulating function of forests as a result of forest fires and numerous cuttings already have their consequences, primarily experienced by the inhabitants of coast villages. For instance, in the Pribaikalsky district local people complained about drying out of their wells that they have to dig deeper and deeper. In the Kabansky district omul stopped entering girts. In Krasny Yar village there is not enough water for pumps in the wells. The same situation is observed in Kika village. If before the wells were 5 - $6 \mathrm{~m}$ deep, nowadays they have 28-meter wellholes. In the village of Maksimikha of the Barguzin district water level in 12 private wellholes got too low. The same problems were reported in Barguzin, Khorinsk, and suburbs of Ulan-Ude. A resident of Zun-Khurai hamlet in the Khorinsk district said that in the vicinity of his settlement Shuluntin-Gorkhon spring, creeks in Barun-Khurai creek valley and Zun-Khurai nick, Zhibarevsky, Cherepanovsky and Khadasunsky springs, two Oinur lakes and Ekhin-Khurai spring ran dry. Also the majority of creeks around Gremyachinsk village, a steppe lake in Kizhinga and two swimming lakes in the Khorinsk district also ran dry [5]. Nowadays a necessity ripens to carry out a full-scale inventory of small streams and creeks flowing into Lake Baikal and clarification of the real number of Baikal's tributaries, which, in reality, considerably decreased and can hardly amount to 300 .

\subsection{The Angara Hydro Power Plants (HPPs)}

Nowadays Lake Baikal is a water body with an artificially regulated runoff. Its water level is to a high degree 
determined by the operating conditions of the Angara HPP chain producing the cheapest electric power in the country. According to the 2001 Decree of the Government of the Russian Federation, in order to avoid negative environmental impacts of power industry power engineers have to observe hydrological regime. Fluctuation of Lake Baikal's level is permissible within the level interval from 456 to $457 \mathrm{~m}$ [6]. Water stored in the Baikal depression is the main power source for the Angara HPP chain. With that, its bulk is situated within the boundaries of the Republic of Buryatia. However all revenues from operating the Angara HPP chain regulating the level of Lake Baikal lying in the territories of two subjects of the federation (Irkutsk region and Republic of Buryatia) were and still are solely in the possession of the Irkutsk region. In this way, the difference in electric power prices for two neighboring federation subjects is of high interest. For instance, urban population of the Republic of Buryatia pays 4.09 RUR per kWh and rural population pays 2.863 RUR per kWh. In the Irkutsk region the price per $\mathrm{kWh}$ for urban population is only $0.84 \mathrm{RUR}$, for rural population- $0.588 \mathrm{RUR}$. Electricity tariffs for industry are much higher.

Such unjust distribution of hydropower rent generated as a result of exploitation of shared Lake Baikal leads to a significant appreciation of any manufacturing in the territory of the Republic of Buryatia in comparison with the Irkutsk region and results in increased costs for population, which is forced to overpay for electricity by almost 5 times. Besides, power engineers from Irkutsk are accused of low-flow of Lake Baikal this year. According to Irkutsk environmentalists, this situation was sparked by several reasons. First, in 2014 there was a recordlow amount of precipitations. Second, since spring 2014 the Irkutsk HPP discharges more water to fill the Boguchanskoe reservoir. And third, construction workers illegally mined gravel in the bed of the Angara River. As a result, the power workers had to discharge more water, which caused the river to cave in by a meter [7]. As a consequence of the low-flow a threat to energy, water and heat supply of public amenities and industrial enterprises of the Angara basin emerged. The Russian government reconsidered critical water mark of Lake Baikal set in 2001 and allowed using water resources of the lake below the designated minimal value to ensure normal operating conditions of all economic entities in the conditions of low-flow of 2014-2015 despite possible negative consequences for Baikal's ecosystem.

\subsection{Mongolian HPPs}

In these complicated circumstances for the survival of Lake Baikal's ecosystem Mongolian plans of constructing six hydro power plants in the Selenga basin cause a lot of concern. Mongolia aims to launch large-scale economic development of the Selenga River basin. Construction of dams is planned both on the body of the river and the Selenga's tributaries, such as the Orkhon, Tuul, Delgermuren and Egiin-Gol. Besides, there is also the Orkhon-Gobi water transfer project, which includes construction of a reservoir on the main tributary of the Selenga - the Orkhon River, as well as construction of a water passageway to the Gobi desert for the needs of mining companies. In April 2015 news spread about agreements reached between Mongolia and the World Bank on investments into the construction of the HPP on the Selenga River and about the intention of the Mongolian authorities to ask the Export-Import Bank of China for a 1 billion USD loan to finance construction of the 315Mwt Egiin-Gol HPP. The deal is to be concluded by the end of 2015 [8]. The construction of Mongolian HPPs may bring Russia a lot of economic and environmental damage. Besides, for the world it may mean the loss of $20 \%$ of pure fresh water in Lake Baikal, which is already endangered without these projects.

\section{Conclusions}

The main ecological-economic problems of the Baikal basin are as follows: the "Baikal factor" limits the development of the local economy; biological contamination of warm shallow bays suitable for swimming may discourage potential tourists; accidental and arson-based forest fires and illegal logging directly harms forest ecosystems of Lake Baikal, as a result of which the water-regulation function of forests is disrupted. This already resulted in running dry of creeks and streams, phreatic decline and combustion of coastal peat bogs. The ecological-economic problems also include the decline of fish stocks which affects wellbeing of coastal areas' population, excessive runoff regulation by HPPs and unjust distribution of hydropower rent. The projected construction of HPPs in Mongolia may result in the destruction of the unique lake, considerable losses in economy and decline in the quality of life of population of the entire Baikal region.

For the preservation of unique Lake Baikal, storage of a huge amount of fresh water, the ecosystem approach should prevail over here-and-now profits of separate groups of people interested in quick revenues without con- 
sideration of long-term ecological consequences. Russian and Mongolian authorities need to remember that the Baikal basin is a transboundary ecological-economic system where everything is interconnected. Wellbeing of the one side depends on the decisions made by the other. Moreover, at the moment Lake Baikal already faces too many problems.

\section{References}

[1] Akimova, T.A. and Khaskin, V.V. (2006) Economy of Nature and Man. Economics, Moscow. [Akimova, T.A. and Khaskin, V.V. (2006) Ekonomika Prirody i Cheloveka. Ekonomika, Moskva].

[2] (2013) State Report: On the Condition and Use of Water Resources of the Russian Federation in the Year 2012. [Gosudarstvennyy doklad: O sostoyanii i ispol'zovanii vodnykh resursov Rossiyskoy Federatsii v 2012 godu]. NIA-Priroda, $370 \mathrm{~s}$.

[3] (2014) State Report: On the Condition of Lake Baikal and Measures to Protect It in the Year 2013 [Gosudarstvennyy doklad: O sostoyanii ozera Baykal i merakh po ego okhrane v 2013 godu]. Sibirskiy filial FGUNPP "Rosgeolfond”, Irkutsk, $462 \mathrm{~s}$.

[4] Bazarova, B.B. and Pronin, N.M. (2006) The Canadian Pondweed in the Chivyrkuy Bay of Lake Baikal. Geography and Natural Resources, 1, 59-62. [Bazarova, B.B. and Pronin, N.M. (2006) Elodeya kanadskaya v Chivyrkuyskom zalive oz. Baykal Geografiya i prirodnye resursy, 1, 59-62].

[5] Aktinov, L. (2015) In Several Years the "Pearl of Siberia” May Turn to a Bog. [Leonid Aktinov (2015) Cherez neskol’ko let “zhemchuzhina Sibiri” mozhet prevratit'sya v boloto]. http://infpol.ru/obshchestvo2/item/10827-cherez-neskolko-let-zhemchuzhina-sibiri-mozhet-prevratitsya-v-boloto/1082 7-cherez-neskolko-let-zhemchuzhina-sibiri-mozhet-prevratitsya-v-boloto.html

[6] Tulokhonov, A.K. (2013) Once Again on the Price of Baikal. ECO, 2, 61-68. [Tulokhonov, A.K. (2013) Eshche raz o tsene Baykala. EKO, 2, 61-68].

[7] Rikhvanova, M. (2015) HPP and Construction are to Blame in the Low-Flow on Lake Baikal. [Marina Rikhvanova (2015) GES i stroiteli vinovaty v malovod'e Baykala—ekspert]. http://news.ircity.ru/4745/

[8] Kolotov, A. (2015) Negotiations on HPP in Mongolia: Moscow Surrenders Baikal. [Aleksandr Kolotov (2015) Peregovory po GES v Mongolii: Moskva sdaet Baykal]. http://www.plotina.net/moskva-sdaet-baikal/ 